\title{
Influence of Seed Fortification on Growth, Yield and Yielding Attributes of Cluster Bean [Cyamopsis tetragonaloba (L).]
}

\author{
Tavva Obul Reddy ${ }^{1 *}$, Bishnu Pratap Singh ${ }^{2}$, Arun Kumar Chaurasia ${ }^{1}$, \\ Hareesh Babu ${ }^{1}$ and S. Venugopal Reddy ${ }^{1}$
}

${ }^{1}$ Department of Genetics and Plant Breeding, Naini Agricultural Institute, Sam Higginbottom

University of Agriculture, Technology and Sciences, Prayagraj, 211007 U. P., India

${ }^{2}$ Director, State Institute for Management of Agriculture, Department of Agriculture, Govt. of. Uttar Pradesh, India

*Corresponding author

\section{A B S T R A C T}

\begin{tabular}{|l|}
\hline Key w o r d s \\
Cluster bean, \\
Treatment \\
Combinations, \\
Fortification, \\
Growth, Yield \\
\hline Article Info \\
\hline $\begin{array}{l}\text { Accepted: } \\
\text { 20 May 2020 } \\
\text { Available Online: } \\
\text { 10 June 2020 }\end{array}$ \\
\hline
\end{tabular}

Cluster bean (Cyamopsis tetragonoloba L.) popularly known as guar is a drought tolerant, deep-rooted, annual legume is grown for Vegetable, Food, Fodder, Green manure, Gum and as a seed. The fortification of seeds for better Growth and Yield has become important and emphasized. The study was conducted to determine the "Influence of seed fortification on growth, yield and seed quality in cluster bean (Cyamopsis tetragonaloba (L).). The experiment was carried out at Field Experimentation Centre of the Department of Genetics and Plant Breeding, Sam Higginbottom University of Agriculture, Technology \& Sciences. Prayagraj (UP) during Kharif-2019. The experiment was laid out in Randomised Blocked Design and comprised of 13 treatments and 3 replications. The treatments were $\mathrm{T}_{0}$ (Control), $\mathrm{T}_{1}\left(\mathrm{KH}_{2} \mathrm{PO}_{4} @ 1 \%\right), \mathrm{T}_{2}\left(\mathrm{ZnSO}_{4} @ 1 \%\right), \mathrm{T}_{3}\left(\mathrm{MgSO}_{4} @ 1 \%\right), \mathrm{T}_{4}\left(\mathrm{KNO}_{3} @ 2 \%\right), \mathrm{T}_{5}$ (Gibberlic Acid@ 200 ppm), T 6 (Salislic Acid@2 ml), T (Pongamia Leaf Extract@ 1\%), $\mathrm{T}_{8}$ (Moringa Leaf Extract@1\%), T 9 (Curry Leaf Extract@1\%), $\mathrm{T}_{10}$ (Neem Seed Kernal Extract@5\%), $\mathrm{T}_{11}\left(\right.$ Cow Urine@10\%), $\mathrm{T}_{12}$ (Coconut Water@20 ml) with a soaking duration of 3 hours. The results revealed that seeds fortified withT $-\mathrm{KH}_{2} \mathrm{PO}_{4} @ 1 \%$ improved Germination $\%$ and $\mathrm{T}_{4}\left(\mathrm{KNO}_{3} @ 2 \%\right)$ improved the Growth, yield and yielding attributes and the least performance was observed in $\mathrm{T}_{0}$ (control) when compared with other treatments. There was an improvement in seed yield due to $\mathrm{T}_{4}\left(\mathrm{KNO}_{3} @ 2 \%\right)$ fortification than unfortified seeds. Hence, seed fortification with $2 \%$ of $\mathrm{KNO}_{3}$ could be recommended for cluster bean as a pre-sowing seed treatment.

\section{Introduction}

Cluster bean (Cyamopsis tetragonoloba (L).) also known as gaur, guwar, or guvar bean is an annual self-pollinated leguminous crop and belongs to the family Fabaceae (Hymowitz and Matlock, 1963). The origin of the Cluster bean has been suggested in India and Pakistan and tropical Africa (Vavilov, 1951). It is assumed to have developed from the African species Cyamopsis senegalensis. It is a drought tolerant, deep-rooted, annual legume, used as vegetable, Seed, Green manure, Fodder. It is also used for making gum, which 
is used in Oil refinaries and Petroleum Industry. It is an important short duration (90120 days) crop of high nutritive valve having high nitrogen fixing ability and is grown during kharif as well as summer seasons in arid and semi-arid regions of India. Cluster bean is cultivated mostly in India, Pakistan, USA, Italy, Morocco, Germany, and Spain (Punia et al., 2009).

Young pods are good source of protein, carbohydrate, vitamins (' $A$ ' and ' $C$ '), and important minerals like calcium and iron (Kumar and Singh 2002). The endosperm of guar seed contains an important hydrocolloid named galactomannan. Mucilaginous seed flour is used for making guar gum (galactomannan) utilized in textile, paper, cosmetic and oil industries throughout the world and is a useful absorbent for explosives (Smith, 1976). The galactomannan due to its thicker, binder and stabilizing specific qualities, has a diversified industrial applications viz. paper, food, cosmetics, explosives, mining, petroleum, pharmaceuticals and well drilling etc. Recent rise in demand of guar in International market as a gum is attributed to its use in mining industry and petrochemical, where its use as viscous agent has been revolutionized the petrochemical industry and resulted in considerable increase in global natural gas production (Falasca et al., 2015). The cluster bean gum used as: (i) agriculture - as anticrushing agent and water retainer, (ii) petroleum industry - as gelling and thickening agent, (iii) textile and juice industry - for sizing, as thickener and stabilizer, (iv) waste water purification - as a gelatinising agent, (v) explosives waterproofing agent, (vi) mining, and (vii) pharmaceutical industries (Girish et al., 2012). Because of its industrial value, guar seed has great demand from foreign countries like USA, Germany, Britain, Italy, France, UAE, China, Japan, South Africa, Hong Kong and Australia etc. Further, cluster bean meal (husk and germ) are used as high protein cattle feed (Rai and Dharmatti, 2013).

India is the major guar producer accounting for $80 \%$ of the world's production. In India, guar is being grown mainly in arid and semiarid regions of North Western states of Rajasthan, Gujarat, Haryana, Punjab, parts of Uttar Pradesh, Madhya Pradesh and Tamil $\mathrm{Nadu}$. It is grown approximately in an area of3.44 million ha, with a production of 2.21 million tonnes and has productivity of $644 \mathrm{~kg} /$ ha (Directorate of Extension and Statistics, 2012). Rajasthan occupies the largest area under guar cultivation (82.1\%), followed by Haryana (8.6\%), Gujarat $(8.3 \%)$ and Punjab (1\%) which in turn produced 64, 22.12 and $2 \%$ guar seeds, respectively (Pathak et al., 2010). Rajasthan is the largest producer accounting for $70 \%$ of total guar production of the country followed by Gujarat, Haryana and Punjab. The productivity of cluster bean ranges from $474 \mathrm{~kg} / \mathrm{ha}$ in Rajasthan to 1200 $\mathrm{kg} / \mathrm{ha}$ in Haryana (Ahlawat et al., 2013).

Seed fortification is one of the ways in which the seedling may have improved competitive ability which may improve the establishment of seedlings under field condition and thereby could compete aggressively with weeds (Cooks, 1980). The Seed fortification has resulted in some outstanding achievements in growth and production of a number of crops. Seed fortification is a physiological method of seed invigoration that aids in improving the initial stamina of seed that helps in improving the initial field stand and that of final yield. Seed fortification is the impregnation of the needy substance into the seed through the imbibition phase and enriches the endogenous level of the needy bioactive substances. Therefore the main objective of seed fortification is to invigorate the seed for better establishment and improved productivity. Sometimes it is also used as protective 
treatment. The seed fortification has resulted in excellent growth and production in number of crops. In the present investigation also, seed fortification had a significant positive influence on the plant growth and seed yield parameters.

\section{Materials and Methods}

The Research study was conducted at experimental research field, Department of Genetics and Plant Breeding, Naini Agriculture Institute, Sam Higginbottom University of Agriculture, Technology and Sciences, Prayagraj during kharif-2019. The experiment was carried out at Field Experimentation Centre of the Department of Genetics and Plant Breeding, Sam Higginbottom University of Agriculture, Technology \& Sciences. Prayagraj (UP) during Kharif-2019.

The source of seed material was obtained from Indian Institute of Pulse Research, Kanpur and the experiment was conducted in Randomized block design (R.B.D) with three replications and the genotype used in this Experiment was GR-6. The data was collected on five randomly selected plants from each plot and measurement of different observations was recorded. The treatments were represented as $\mathrm{T}_{0}$ (Control), $\mathrm{T}_{1}$ $\left(\mathrm{KH}_{2} \mathrm{PO}_{4} @ 1 \%\right), \quad \mathrm{T}_{2} \quad\left(\mathrm{ZnSO}_{4} @ 1 \%\right), \mathrm{T}_{3}$ $\left(\mathrm{MgSO}_{4} @ 1 \%\right), \quad \mathrm{T}_{4} \quad\left(\mathrm{KNO}_{3} @ 2 \%\right), \quad \mathrm{T}_{5}$ (Gibberlic Acid@200 ppm), T6 (Salislic Acid@ $2 \mathrm{ml}$ ), $\quad \mathrm{T}_{7}$ (Pongamia Leaf Extract@ 1\%), $\quad \mathrm{T}_{8} \quad$ (Moringa Leaf Extract@1\%), T (Curry Leaf Extract@1\%), $\mathrm{T}_{10}$ (Neem Seed Kernal Extract @5\%), $\mathrm{T}_{11}$ (Cow Urine@10\%), $\quad \mathrm{T}_{12} \quad$ (Coconut Water@20 ml).

\section{Results and Discussion}

It is evident from the present investigation, influence of seed fortification with $T_{0}$
(Control), $\mathrm{T}_{1} \quad\left(\mathrm{KH}_{2} \mathrm{PO}_{4} @ 1 \%\right), \quad \mathrm{T}_{2} \quad\left(\mathrm{ZnSO}_{4}\right.$ @1\%), $\mathrm{T}_{3}\left(\mathrm{MgSO}_{4} @ 1 \%\right), \mathrm{T}_{4}\left(\mathrm{KNO}_{3} @ 2 \%\right)$, $\mathrm{T}_{5}$ (Gibberlic Acid@200 ppm), T6 (Salislic Acid@ $2 \mathrm{ml}$ ), $\quad \mathrm{T}_{7}$ (Pongamia Leaf Extract@1\%), $\mathrm{T}_{8} \quad$ (Moringa Leaf Extract@1\%), T 9 (Curry Leaf Extract@1\%), $\mathrm{T}_{10}$ (Neem Seed Kernal Extract @ 5\%), $\mathrm{T}_{11}$ (Cow Urine@10\%), $\mathrm{T}_{12}$ (Coconut Water@20 ml) have positive effect on the growth, yield and yield attributes. In general, most of the treatment was found effective in increasing the yield attributes at all stages significantly as compared to control. In the growth, yield attributing parameters such as field emergence, the maximum was recorded in $\mathrm{T}_{1}-\mathrm{KH}_{2} \mathrm{PO}_{4} @ 1 \%(94.07)$ and it was followed by $\mathrm{T}_{5}$-Gibberlic acid @ 200 ppm, (92.08) and the lowest was Observed in $\mathrm{T}_{0^{-}}$ control, (82.87).

In Plant Height the maximum was recorded in $\mathrm{T}_{4}-\mathrm{KNO}_{3} @ 2 \%(129 \mathrm{cms})$ and it was followed by $\mathrm{T}_{1}-\mathrm{KH}_{2} \mathrm{PO}_{4} @ 1 \%(120.33 \mathrm{cms})$ and the lowest was observed in $\mathrm{T}_{0}$-control, $(79 \mathrm{cms}) . I n$ Days to $50 \%$ Flowering and Days to maturity the maximum was recorded in treatment $\mathrm{T}_{0}$ (control) and it was followed by treatment $\mathrm{T}_{12}$ (Coconut Water@20 ml) and the the minimum Days to $50 \%$ flowering and Days to $50 \%$ maturity was recorded in $\mathrm{T}_{4}$ $\left(\mathrm{KNO}_{3} @ 2 \%\right)$. However in No. of clusters/plant, No. of Pods/clusters, No. of Pods/plant, Pod length (cm), Seed yield/plot (gm), the maximum was recorded in $\mathrm{T}_{4}\left(\mathrm{KNO}_{3} @ 2 \%\right)$ and it was followed by $\mathrm{T}_{2}\left(\mathrm{ZnSO}_{4} @ 1 \%\right)$ with the least recorded in $\mathrm{T}_{0}$ (control).

Based on the present investigation it is concluded that the treatment combination $\mathrm{T}_{1^{-}}$ $\mathrm{KH}_{2} \mathrm{PO}_{4} @ 1 \%$ was found best in terms of Field emergence and the treatment combination $\mathrm{T}_{4}\left(\mathrm{KNO}_{3} @ 2 \%\right)$ was found best in the Growth and Yield parameters and it was followed by treatment $\mathrm{T}_{2}\left(\mathrm{ZnSO}_{4} @ 1 \%\right)$ as compared to the treatment $\mathrm{T}_{0}(\mathrm{Control})$. 
Table.1 Mean performance of growth and yield parameters in cluster bean

\begin{tabular}{|c|c|c|c|c|c|c|c|c|c|}
\hline Treatments & $\begin{array}{c}\text { Field } \\
\text { emergence }\end{array}$ & $\begin{array}{c}\text { Plant } \\
\text { height } \\
(\mathrm{cm})\end{array}$ & $\begin{array}{c}\text { Days to } \\
50 \% \\
\text { flowering }\end{array}$ & $\begin{array}{l}\text { Days to } \\
\text { maturity }\end{array}$ & $\begin{array}{c}\text { No. of } \\
\text { clusters/plant }\end{array}$ & $\begin{array}{c}\text { No. of } \\
\text { Pods/clusters }\end{array}$ & $\begin{array}{c}\text { No. of } \\
\text { Pods/plant }\end{array}$ & $\begin{array}{c}\text { Pod } \\
\text { length } \\
(\mathrm{cm})\end{array}$ & $\begin{array}{c}\text { Seed } \\
\text { yield/plot } \\
(\text { gm) }\end{array}$ \\
\hline $\mathbf{T}_{\mathbf{0}}$ & 82.87 & 79.00 & 36.33 & 108.33 & 9.83 & 3.82 & 37.622 & 6.80 & 313.38 \\
\hline $\mathbf{T}_{1}$ & 94.07 & 120.33 & 28.33 & 97.33 & 11.67 & 4.95 & 57.666 & 8.26 & 370.28 \\
\hline $\mathbf{T}_{2}$ & 91.79 & 103.67 & 27.33 & 95.33 & 12.10 & 5.30 & 64.0767 & 9.11 & 391.72 \\
\hline $\mathbf{T}_{\mathbf{3}}$ & 88.66 & 119.00 & 27.67 & 96.33 & 11.93 & 5.13 & 61.2833 & 8.69 & 384.61 \\
\hline $\mathbf{T}_{4}$ & 90.33 & 129.00 & 26.33 & 94.67 & 12.67 & 5.83 & 73.8633 & 9.83 & 416.65 \\
\hline $\mathbf{T}_{5}$ & 92.08 & 117.33 & 28.67 & 97.67 & 11.97 & 4.95 & 59.2687 & 8.57 & 373.60 \\
\hline $\mathbf{T}_{6}$ & 87.30 & 107.33 & 29.33 & 98.33 & 11.30 & 4.42 & 49.9863 & 7.86 & 369.83 \\
\hline $\mathbf{T}_{7}$ & 89.14 & 98.67 & 32.67 & 102.33 & 10.50 & 4.54 & 47.6777 & 8.55 & 365.12 \\
\hline $\mathbf{T}_{8}$ & 88.18 & 93.00 & 34.33 & 104.67 & 10.53 & 4.26 & 44.8667 & 7.82 & 341.40 \\
\hline $\mathbf{T}_{9}$ & 85.42 & 99.00 & 33.67 & 103.33 & 10.27 & 4.33 & 44.4703 & 7.22 & 323.16 \\
\hline $\mathbf{T}_{10}$ & 87.07 & 118.00 & 31.33 & 100.33 & 10.10 & 4.79 & 48.4033 & 7.35 & 349.37 \\
\hline $\mathbf{T}_{11}$ & 90.23 & 106.67 & 30.67 & 99.67 & 11.47 & 4.43 & 50.7967 & 8.75 & 377.34 \\
\hline $\mathbf{T}_{12}$ & 85.82 & 93.67 & 34.67 & 105.67 & 10.73 & 4.40 & 47.1667 & 7.36 & 334.92 \\
\hline Mean & 88.69 & 106.51 & 30.87 & 100.31 & 11.16 & 4.71 & 52.8575 & 8.17 & 362.41 \\
\hline CD & 1.65055 & 3.39366 & 0.62802 & 0.958 & 0.57028 & 0.15667 & 2.71496 & 0.17831 & 16.7614 \\
\hline SE. $m$ & 0.97946 & 2.01384 & 0.37267 & 0.569 & 0.33841 & 0.09297 & 1.61109 & 0.10581 & 9.94642 \\
\hline SE. d & 0.79973 & 1.64429 & 0.30429 & 0.4643 & 0.27631 & 0.07591 & 1.31545 & 0.08639 & 8.12122 \\
\hline
\end{tabular}




\section{References}

Ahlawat, A, Pahuja, S. K and Dhingra, H. R. 2013. Studies on interspecific hybridization in Cyamopsis species. African J. Agric, 8(27): 3590-3597.

Aravind Jukanti, R. K. Bhatt, Ramavtar Sharma and R.K. Kalia, 2015. Morphological, agronomic, and yield characterization of cluster bean (Cyamopsis tetragonoloba L.) germplasm accessions. J. Crop Sci. Biotech. 2015 (March) 18 (1): $00 \sim 00$.

DAVIES, P. J., 1995, The plant hormones: their nature, occurrence, and functions. In PJ Davies, ed, Plant hormones: Physiology, Biochemistry and Molecular Biology. Kluwer Academic Publishers, Dordrecht, The Netherlands, pp $1-12$.

Directorate of Extension and Statistics, Government of India. 2012. Area, production, and productivity of clusterbean in India.

Dodla Rajashekar Reddy, P. Saidaiah, K. Ravinder Reddy and Pandravada, S.R. 2017. Mean Performance of Cluster Bean Genotypes for Yield, Yield Parameters and Quality Traits. Int.J.Curr.Microbiol.App.Sci. $\quad$ 6(9): 3685-3693.

Falasca, S.L., Miranda, C., and Pitta-Alvarez, S. (2015). Modeling an agroclimatic zoning methodology to determine the potential growing areas of Cyamopsis tetragonoloba (cluster bean) in Argentina. Advance Applied and Agriculture Sciences, 3: 23-39.

Girish MH, Gasti VD, Thammaiah N, Kerutagi MG, Mulge R, Shantappa T, Mastiholi AB. 2012. Genetic divergence studies in cluster bean (Cyamopsis tetragonoloba (L.) Taub.). Karnataka J. Agric. Sci. 25: 245-247.

Hari Singh Meena, K.B. Suneetha Devi and Suresh, G. 2016. Yield and profitability of clusterbean (Cyamopsis tetragonoloba) as influenced by varieties and crop geometry in semi-arid climate of Andhra Pradesh. Indian Journal of Agronomy. 61 (3): 401-403.

Hymowitz T, Matlock RS. 1963. Cluster Bean in the United States. Oklahoma Agricultural Exper. Station Technical Bull. 611: 1-34.

Kumar D, Singh NB. 2002. Guar in India. Scientific Publishers, Jodhpur, India, $1-5$.

NRAA, 2014, Potential of Rainfed Guar (Cluster beans) Cultivation, Processing and Export in India. Policy paper No.3 National Rainfed Area Authority, NASC Complex. DPS Marg, New Delhi-110012, India, pp 109.

Pathak, R, Singh, S.K, Singh, M and Henry, A. 2010. Molecular assessment of genetic diversity in cluster bean (Cyamopsis tetragonoloba) genotypes. J. Genet. 89: 243-246.

Punia A, Yadav R, Arora P, Chaudhury A. 2009. Molecular and morphophysiological characterization of superior cluster bean (Cymopsis tetragonoloba) varieties. J. Crop Sci. Biotechnol. 12: 143-14.

Rai PS, Dharmatti PR. 2013. Genetic divergence studies in cluster bean (Cyamopsis tetragonoloba (L.) Taub.). Global J. Sci. Frontier Res. Agri. Veterinary 13: 1-5.

Renugadevi, J. and Vijayageetha, V., 2007, Organic seed fortification in cluster bean (Cyamopsis tetragonoloba L.) TAUB. International conference on indigeneous vegetables and Legumes. Acta Hort., 335-338.

Renugadevi, J., Natarajan, N., and Srimathi, P., 2008, Influence of inorganic nutrients on improving the seeds and seedling quality characteristics of 
cluster bean, Legume Res., 31(3): 206-209.

Smith, P. M. 1976. Evolution of Crop Plants (ed. N. W. Simmonds), Longman, London and New York, pp. 311-312.

Sukhdeep Singh, Baldeep Singh and Gajraj Singh, 2017. Genetic divergence studies in clusterbean (Cyamopsis tetragoloba (L.) Taub.) genotypes for seed yield and gum content under rain-fed conditions. Journal of Applied and Natural Science 9 (1): 389 - 394 (2017).

Umesha and Chennakeshava, B.C. Influence of seed fortification on growth, yield and Yielding attributes of cluster bean (Cyamopsis tetragonoloba (L.) Taub). Mysore Journal of Agricultural Sciences. Pp. 306-309.

Vavilov, N.I. (1951). The origin, variation, immunity and breeding of cultivated plants. Chronica Botanica 13.

\section{How to cite this article:}

Tavva Obul Reddy, Bishnu Pratap Singh, Arun Kumar Chaurasia, Hareesh Babu and Venugopal Reddy, S. 2020. Influence of Seed Fortification on Growth, Yield and Yielding Attributes of Cluster Bean [Cyamopsis tetragonaloba (L).]. Int.J.Curr.Microbiol.App.Sci. 9(06): 2576-2581. doi: https://doi.org/10.20546/ijcmas.2020.906.313 